\title{
PENERAPAN MODEL PEMBELAJARAN BERBASIS PROYEK PADA MATA KULIAH KONSEP DASAR GEOMETRI DAN PENGUKURAN UNTUK MENINGKATKAN KETERAMPILAN MEMBUAT ALAT PERAGA BAGI MAHASISWA PGSD
}

\author{
Neza Agusdianita \\ Neza.agusdianita@unib.ac.id \\ Pendidikan Guru Sekolah Dasar \\ Fakultas Keguruan dan Ilmu Pendidikan, Universitas Bengkulu
}

\begin{abstract}
Abstrak
Penelitian ini bertujuan untuk dapat meningkatan kualitas proses pembelajaran pada mata kuliah konsep dasar geometri dan pengukuran dan meningkatkan keterampilan mahasiswa PGSD dalam membuat alat peraga matematika melalui penerapan model pembelajaran berbasis proyek pada mata kuliah konsep dasar geometri dan pengukuran. Jenis penelitian yang dilakukan adalah penelitian tindakan kelas yang dilaksanakan dalam 2 siklus. Setiap siklus terdiri dari empat tahap yaitu tahap perencanaan, pelaksanaan tindakan, observasi dan refleksi. Instrumen yang digunakan adalah lembar observasi keaktifan mahasiswa dan lembar observasi keterampilan mahasiswa dalam membuat alat peraga. data hasil penelitian dianalisis secara deskriptif. Dari analisis data menunjukkan bahwa pada siklus I diperoleh nilai rata-rata skor observasi keaktifan mahasiswa sebesar 36 dengan kriteria baik dan untuk nilai rata-rata skor observasi keterampilan mahasiswa sebesar 36 dengan kriteria baik. pada siklus II terjadi peningkatan yaitu untuk nilai ratarata skor observasi keaktifan mahasiswa sebesar 47,5 dengan kriteria amat baik dan nilai rata-rata skor observasi keterampilan mahasiswa sebesar 45,5 dengan kriteria amat baik. Dengan demikian dapat disimpulkan bahwa penerapan model pembelajaran berbasis proyek pada mata kuliah konsep dasar geometri dan pengukuran dapat meningkatkan keterampilan membuat alat peraga bagi mahasiswa PGSD.
\end{abstract}

Kata Kunci: Model Pembelajaran Berbasis Proyek, Geometri dan Pengukuran, Alat Peraga

\section{PENDAHULUAN}

Paradigma pembelajaran di perguruan tinggi dewasa ini menuntut mahasiswa yang lebih aktif dalam pembelajaran. Hal tersebut sesuai dengan peraturan menteri pendidikan dan kebudayaan nomor 49 Tahun 2014 tentang Standar Nasional Pendidikan Tinggi (SNPT). Isi dari permendikbud tersebut yaitu pembelajaran di perguruan tinggi harus memiliki karakteristik interaktif, holistik, integratif, saintifik, kontekstual, tematik, efektif, kolaboratif, dan berpusat pada mahasiswa (Kemendikbud, 2014).
Berdasarkan paradigma di atas dosen harus mampu menerapkan model pembelajaran yang sesuai dengan karakteristik seperti tercantum dalam SNPT. Salah satu model yang sesuai dengan karakteristik tersebut yaitu model pembelajaran berbasis proyek (Project-Based Learning/PjBL).

Model PjBL sangat cocok diterapkan pada mata kuliah konsep dasar geometri dan pengukuran. Mata kuliah ini membekali mahasiswa tentang konsep - konsep matematika dan bagaimana proses pembelajarannya. Dengan menerapkan model ini maka mahasiswa akan 
memiliki banyak pengalaman dalam merencanakan pembelajaran matematika yang berkualitas dan terampil dalam menciptakan alat peraga yang dibutuhkan.

Pembelajaran matematika di SD adalah proses pemberian pengalaman belajar kepada peserta didik melalui serangkaian kegiatan yang terencana sehingga peserta didik memperoleh kompetensi tentang materi matematika yang dipelajari Muhsetyo (2011). Oleh karena itu, pengalaman belajar yang diberikan oleh dosen bertujuan agar mahasiswa memahami materi matematika, memiliki kemampuan untuk memecahkan masalah dalam matematika, serta terampil dalam menciptakan alat peraga yang dibutuhkan.

Alat peraga salah satu faktor penting dalam pembelajaran matematika di SD. Pembelajaran matematika akan bermakna bagi mahasiswa jika pembelajaran mengutamakan penanaman konsep dan pemahaman, bukan sekedar pembelajaran dengan menyelesaikan latihan-latihan praktis menyelesaikan soal secara ringkas (Agusdianita, 2013). Dengan demikian melalui mata kuliah ini diharapkan akan dapat menghasilkan berbagai alat peraga yang dapat digunakan dalam menanamkan konsep matematika di SD.

\section{METODE}

Jenis penelitian ini adalah penelitian tindakan kelas. Penelitian tindakan kelas ini merupakan penelitian yang dilakukan oleh dosen di dalam kelasnya sendiri melalui refleksi diri dengan tujuan untuk memperbaiki kinerjanya sebagai dosen sehingga kualitas proses dan hasil belajar mahasiswa meningkat (Wardhani, 2007). Subjek penelitian ini adalah mahasiswa semester III Program Studi PGSD Universitas Bengkulu. Data pada penelitian ini dikumpulkan melalui observasi. Instrumen yang digunakan dalam penelitian ini adalah yaitu lembar observasi keaktifan mahasiwa dan lembar observasi keterampilam mahasiswa. Prosedur penelitian ini terdiri dari empat tahap yaitu: (1) perencanaan (Planing), (2) pelaksanaan tindakan (action), (3) pengamatan (observation), dan (4) refleksi (reflektion) (Arikunto, 2006). Data hasil penelitian ini dianalisis secara deskriptif dengan ketentuan skor untuk setiap aspek yang diamati.

\section{HASIL}

Dari hasil penelitian yang telah dilakukan dengan menerapkan model model pembelajaran berbasis proyek pada mata kuliah konsep dasar geometri dan pengukuran diperoleh hasil observasi sebagai berikut:

\section{Siklus I}

\section{Deskripsi Observasi terhadap Keaktifan Mahasiswa}

Hasil observasi terhadap keaktifan mahasiswa selama mengikuti pembelajaran dengan menerapkan model pembelajaran berbasis proyek pada mata kuliah konsep dasar geometri dan pengukuran menunjukkan bahwa rata-rata skor sebesar 36. Rata-rata skor ini termasuk pada kategori baik. Dengan demikian dapat diartikan bahwa keaktifan mahasiswa pada pembelajaran ini sudah baik. Namun masih terdapat kelemahan pada aspek diskusi hasil kerja kelompok.

\section{Deskripsi Observasi terhadap Keterampilan Mahasiswa}

Hasil observasi terhadap keterampilan mahasiswa selama mengikuti pembelajaran dengan menerapkan model pembelajaran berbasis proyek pada mata kuliah konsep dasar geometri dan pengukuran menunjukkan bahwa rata-rata skor sebesar 36. Rata-rata skor ini termasuk pada kategori baik. Dengan demikian dapat diartikan bahwa keteramp." nahasiswa pada pembelajaran ini sudah bail nun masih terdapat kelemahan pada aspek kerja sama dalam kelompok.

\section{Refleksi siklus I}

Berdasarkan hasil analisis terhadap keaktifan dan keterampilan mahasiswa masih 
terdapat beberapa aspek yang masih pada kategori cukup yaitu keaktifan mahasiswa dalam presentasi dan diskusi hasil kerja kelompok serta dalam membuat alat peraga masih ada mahasiswa yang tidak bekerja sama dan hasil produk alat peraga juga belum sempurna.

Langkah-langkah yang penulis lakukan untuk mengatasi kelemahan pada siklus I yaitu: (1) memperjelas prosedur pembelajaran, (2) memberikan kesempatan kepada semua mahasiswa untuk memberikan pendapat saat diskusi, (3) membimbing mahasiswa dalam membuat alat peraga dalam kelompok.

\section{Siklus II}

\section{Deskripsi Observasi terhadap Keaktifan Mahasiswa}

Hasil observasi terhadap keaktifan mahasiswa selama mengikuti pembelajaran dengan menerapkan model pembelajaran berbasis proyek pada mata kuliah konsep dasar geometri dan pengukuran menunjukkan bahwa rata-rata skor sebesar 45,5. Rata-rata skor ini termasuk pada kategori amat baik. Dengan demikian dapat diartikan bahwa keaktifan mahasiswa pada pembelajaran ini sudah amat baik.

\section{Deskripsi Observasi terhadap Keterampilan Mahasiswa}

Hasil observasi terhadap keterampilan mahasiswa selama mengikuti pembelajaran dengan menerapkan model pembelajaran berbasis proyek pada mata kuliah konsep dasar geometri dan pengukuran menunjukkan bahwa rata-rata skor sebesar 47,5. Rata-rata skor ini termasuk pada kategori amat baik. Dengan demikian dapat diartikan bahwa keterampilan mahasiswa pada pembelajaran ini sudah amat baik.

\section{Refleksi siklus II}

Berdasarkan hasil analisis terhadap keaktifan dan keterampilan siswa menjukkan terdapat peningkatan yaitu dari kategori baik pada siklus I menjadi kategori amat baik pada siklus II. Hal tersebut ditunjukkan dengan ratarata skor pada keaktifan siswa pada siklus I sebesar 36 menjadi 45,5 pada siklus II. Selanjutnya untuk keterampilan mahasiswa ratarata skor pada siklus I sebesar 36 dan meningkat menjadi 47,5 pada siklus II.

\section{PEMBAHASAN}

Penelitian ini menerapkan model PjBL dalam mata kuliah konsep dasar geometri dan pengukuran pada mahasiswa semester III Prodi PGSD FKIP Unib. Model PjBL merupakan suatu model yang berbeda dari model tradisional lainnya dengan fokus utama menempatkan mahasiswa dalam proyek nyata. Mahasiswa diberikan kesempatan untuk merancang sampai menciptakan alat peraga matematika yang dapat digunakan untuk mengajarkan konsep geometri dan pengukuran di SD.

Model ini diawali oleh gagasan dari Dewey tentang konsep "learning by doing" yakni pemerolehan hasil belajar dengan mengerjakan tindakan-tindakan tertentu sesuai dengan tujuannya, terutama proses penguasaan anak tentang bagaimana melakukan sesuatu pekerjaan yang terdiri atas serangkaian tingkah laku untuk mencapai tujuan. Dengan demikian diharapkan dengan menerapkan model ini keterampilan mahasiswa dalam menciptakan alat peraga matematika meningkat.

Hasil penelitian menunjukkan terjadi peningkatan keaktifan mahasiswa di kelas saat pembelajaran geometri dan pengukuran. Hal tersebut dibuktikan dengan kenaikan rata-rata skor observasi yang pada siklus I berada pada kategori baik menjadi amat baik pada siklus II. Keaktifan mahasiswa ditunjukkan dengan semangat mahasiswa mengikuti perkuliahan, mahasiswa menjadi tertantang dan bersemangat dalam menyelesaikan proyek-proyek yang diberikan oleh dosen.

Selanjutnya keterampilan mahasiswa dalam membuat alat peraga juga meningkat. Hal tersebut dibuktikan dengan kenaikan rata-rata 
skor observasi yang pada siklus I berada pada kategori baik menjadi amat baik pada siklus II. Mahasiswa menjadi tanggap dan jeli dalam merencanakan dan membuat alat peraga apa yang menarik dan efektif digunakan di SD.

Dengan memiliki keterampilan membuat alat peraga akan memudahkan mahasiswa dalam menjalani profesi guru nantinya. Mahasiswa tidak harus membeli alat peraga yang harganya cukup mahal. Mahasiswa dapat berkreasi dan membuat alat peraganya sendiri. Sehingga akan memberi nilai tambah bagi lulusan PGSD.

Bruner dalam Karso (2003) menambahkan bahwa proses pembelajaran matematika di Sekolah Dasar dibedakan menjadi tiga tahap yaitu tahap satu dimulai dari model konkret yaitu menggunakan benda-benda nyata, tahap dua yaitu model semi konkret (model gambar) dan tahap tiga menggunakan simbol secara abstrak. Untuk itu diperlukan alat peraga untuk dapat menjembatani materi-materi matematika yang abstrak untuk dapat dipahami oleh siswa SD.Hal tersebut sesuai dengan karakteristik siswa SD (712 tahun) berada dalam tahap konkret operasional (Dahar, 2011).

Dengan demikian dengan menerapakan model PjBL ini sangatlah tepat untuk dapat meningkatkan keaktifan dan keterampilan membuat alat peraga bagi mahasiswa PGSD.

\section{SIMPULAN}

Dari hasil penelitian ini dapat ditarik kesimpulan bahwa melalui model pembelajaran berbasis proyek pada mata kuliah konsep dasar geometri dan pengukuran dapat meningkatkan keterampilan membuat alat peraga bagi mahasiswa PGSD.

\section{SARAN}

Berdasarkan hasil penelitian ini maka disarankan untuk: (1) untuk meningkatkan keaktifan dan keterampilan mahasiswa dapat menerapkan model pembelajaran berbasis proyek, (2) Mahasiswa harus dibekali dengan keterampilan membuat alat peraga matematika untuk dapat digunakan saat mereka bekerja sebagai guru.

\section{DAFTAR PUSTAKA}

Agusdianita, Neza. 2013. Pengaruh Model Pembelajaran Quantum Teaching Terhadap Kemampuan Pemahaman Matematik Siswa Sekolah Dasar. Laporan Tesis. Bandung: UPI

Arikunto, suharsimi 2006. Penelitian tindakan kelas. Jakarta: Bumi Aksara

Dahar, Ratna Wilis. (2011). Teori-Teori Belajar dan Pembelajaran. Jakarta: Erlangga

Karso. 2003. Pendidikan Matematika. Jakarta: Universitas Terbuka.

Kementrian pendidikan dan kebudayaan, (2014). Peraturan Menteri Pendidikan dan Kebudayaan Nomor 49 Tahun 2014 tentang Standar Nasional Pendidikan Tinggi. Kemendikbud: Jakarta.

Muhsetyo, Gatot. 2011. Pembelajaran Matematika. Jakarta: Universitas Terbuka.

Slameto. (2010). Belajar \& Faktor-Faktor yang Mempengaruhinya. Jakarta: Rineka Cipta

Wardhani IGAK, 2007. Penelitian tindakan kelas. Jakarta:UT 